Przemyslaw CZERNICKI

Uniwersytet Przyrodniczo-Humanistyczny w Siedlcach ${ }^{1}$

Wydzial Nauk Spolecznych

Instytut Nauk o Polityce i Administracji

przemcz5@wp.pl

ORCID 0000-0002-1184-1556

https://doi.org/10.34739/dsd.2020.02.05

\title{
POLITYKA BEZPIECZEŃSTWA \\ ENERGETYCZNEGO PAŃSTWA POLSKIEGO \\ NA PRZYKŁADZIE GAZOCIĄGU OPAL
}

\begin{abstract}
ABSTRAKT: Przedmiotem niniejszego artykułu jest bezpieczeństwo energetyczne Polski w obliczu liberalizacji rynku energetycznego UE. Celem podjętych badań jest identyfikacja istniejących tutaj dla Polski oraz państw Europy Środkowo-Wschodniej zagrożeń oraz ocena ich skali i skutków ekonomicznych oraz politycznych. Artykuł napisano w oparciu o wykorzystanie metod badawczych bazujących na przede wszystkim na analizie źródeł w postaci dokumentów normatywnych, dostępnych pozycji z literatury przedmiotu, danych porównawczych czy wtórnych stanowiących metodologiczne komponenty stadium przypadku badanego gazociągu OPAL. W artykule dokonano przeglądu wydarzeń i uwarunkowań dotyczących stosowania unijnych regulacji prawnych zmierzających do przeciwdziałania monopolistycznemu zawładnięciu przez rosyjski koncern Gazprom omawianą magistralą przesyłową w kontekście polityki bezpieczeństwa energetycznego prowadzonej przez polskie władze na tle analogicznych działań kilku innych państw regionu.
\end{abstract}

SŁOWA KLUCzOWE: bezpieczeństwo energetyczne, gazociąg, koncern, Polska

\section{THE ENERGY SECURITY POLICY OF POLAND ON THE EXAMPLE OF THE OPAL GAS PIPELINE}

\begin{abstract}
The subject of this article is Poland's energy security in the face of the liberalization of the European Union energy market. The aim of the undertaken research was to identify the threats existing in Poland and countries of Central and Eastern Europe as well as to assess their scale and economic and political effects. The article was primarily based on the following research methods: analysis of sources in the form of normative documents, available literature, comparative or secondary data constituting methodological components of the examined OPAL pipline case study. The article also reviews the events and conditions relating to the application of EU legal regulations aimed at counteracting the monopolistic seizure by the Russian Gazprom of the discussed transmission line in the context of the energy security policy pursued by the Polish authorities against the background of similar activities of several other countries in the region.
\end{abstract}

KEYWORDS: energy security, gas pipeline, consortium, Poland

${ }^{1}$ Siedlce University of Natural Sciences and Humanities; Poland. 


\section{WPROWADZENIE}

Rozpatrując kwestie dotyczące pojęcia bezpieczeństwa energetycznego w sektorze gazowym, warto w szczególności zwrócić uwagę na fakt, iż o ile właściwie każdy kraj jest w stanie wyprodukować energię elektryczną, o tyle tylko nieliczne państwa posiadają na swoich terytoriach złoża gazu umożliwiające eksport tych zasobów. Tym samym strategiczne znaczenie gazu przybiera postać kluczowego elementu dla kreowania rozwoju gospodarczego i funkcjonowania współczesnych społeczeństw. Należy zwrócić też uwagę na zwiększoną zależność krajów unijnych (zwłaszcza położonych w regionie Europy Środkowo-Wschodniej) od importu gazu ziemnego pochodzącego z Rosji (jako państwa posiadającego największe złoża tego surowca na całym świecie). W rezultacie dostawy tego surowca należy rozpatrywać nie tylko w ekonomicznych uwarunkowaniach wzajemnej gry popytu i podaży, lecz także w kategoriach geopolitycznych oraz kwestiach dotyczących bezpieczeństwa współczesnego państwa. Występujące w nieodległej przeszłości konflikty naszego wschodniego sąsiada z Białorusią i Ukrainą na tle dostaw ropy czy gazu świadczą o możności wykorzystywania przez Federację Rosyjską posiadanych zasobów energetycznych jako instrument nacisku politycznego ${ }^{2}$. Patrząc na działania podejmowane od kilkunastu lat w szczególności poprzez wykorzystywanie w tej mierze energetycznego koncernu Gazprom może się więc okazać, że przy użyciu magistrali przesyłowych NORD STREAM czy OPAL realizowana jest w szczególności strategia polegającą na istotnym redukowaniu znaczenia dotychczasowych liderów tranzytu surowców energetycznych w naszym regionie, jakimi były dotychczas Polska i Ukraina.

Jak się wydaje, sens budowy (w okresie lat 2009-2011) magistrali OPAL polegał przede wszystkim właśnie na jej połączeniu z istniejącą na terenie Europy siecią infrastruktury gazowej (vide: rysunek nr 1 oraz $\mathrm{nr}$ 2) oraz jej wyposażeniu w istotne możliwości przesyłowe. Za sprawą bowiem wykorzystania wspomnianych połączeń infrastrukturalnych i uzyskania dostępu do sieci europejskich rurociągów można przesyłać w okolice Berlina w ciągu danego roku $36,5 \mathrm{mld} \mathrm{m}^{3}$, a do Czech niewiele mniej, gdyż $32 \mathrm{mld} \mathrm{m}^{3}$ rosyjskiego gazu rocznie (vide: rysunek $\left.\mathrm{nr} 3\right)^{3}$.

\footnotetext{
${ }^{2} \mathrm{Na}$ temat wykorzystywania geostrategicznego znaczenia surowców energetycznych w szczególności w polityce prowadzonej przez współczesną Rosję oraz bezpieczeństwa energetycznego państw naszego regionu vide zwłaszcza M. Janowski, M. Jastrzębski, Ł. Nowakowski, I. Postawicki, Polityka bezpieczeństwa energetycznego państw Europy środkowo-wschodniej: rola i znaczenie Grupy Wyszehradzkiej, Warszawa 2016;W. Paniuszkin, M. Zygar, Gazprom: rosyjska broń, Warszawa 2008; M. Paszyn, Gazprom na niemieckim rynku energetycznym w okresie rząów Angeli Merkel 2005-2014, Studia Niemcoznawcze, T. 55 (2015); red. E. Wyciszkiewicz, Geopolityka rurociagów: wspótzależność energetyczna a stosunki międzypaństwowe na obszarze postsowieckim, Warszawa 2008; A. Kotłowski, Third-Party Access Rights in the Energy Sector: A Competition Law Perspective, "Utilities Law Review", Vol. 16, No. 3, 2007, M-H. Chen; J. Kulhánek; M. Thim, Energy security in Central and Eastern Europe, Prague 2008; red. W. Ostrowski, E. Butler, Understanding Energy Security in Central and Eastern Europe: Russia, Transition and National Interest. Abingdon, Oxon Routledge 2018.

${ }^{3}$ Dla porównania obecna zdolność regazyfikacyjna polskiego terminalu LNG w Szczecinie wynosi jedynie $5 \mathrm{mld} \mathrm{m}^{3}$ gazu rocznie. Vide: Polskie LNG, https://www.polskielng.pl/terminal-lng/terminal-lng-w-swinoujsciu/ (23.12.2019).
} 


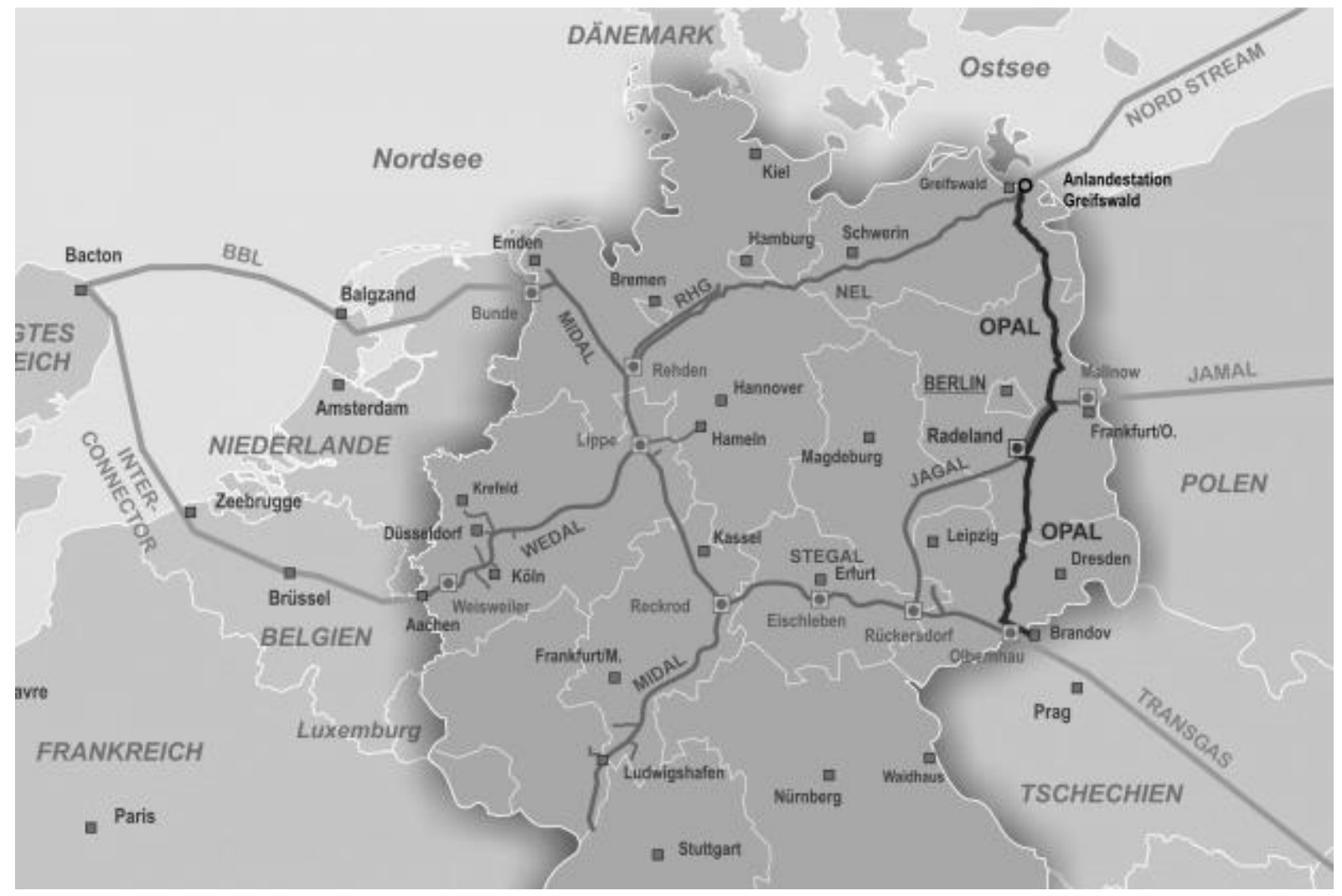

Rysunek 1. Gazociąg OPAL na tle europejskiej sieci gazociągów

Źródło: D. Malinowski, Gazociag Opal - rosyjska macka w Europie, http://gazownictwo.wnp.pl/gazociag-opalrosyjska-macka-w-europie,284347_1_0_0.htm

Warto przy tym zwrócić uwagę na międzynarodową strukturę właścicielską omawianej instytucji. Właścicielem gazociągu OPAL jest bowiem spółka joint-venture WIGA Transport Beteiligungs-GmbH \& Co. KG. (WIGA), której udziałowcami są spółka-córka koncernu BASF - Wintershall Holding GmbH (50,02\%), oraz PAO Gazprom (49,98\%)

Dzięki wykorzystaniu wspomnianych możliwości przesyłowych i infrastrukturalnych Gazprom jest w stanie uzyskać dostęp właściwie do wszystkich ważniejszych rynków energetycznych w Europie. W strategii wdrażanej przez rosyjski koncern gazociąg OPAL wydaje się odgrywać szczególnie istotną rolę, gdyż wykorzystanie jego przepustowości umożliwia w praktyce przekierowywanie rosyjskiego gazu z punktu położonego na granicy czesko-słowackiej w okolicy morawskiego miasta Lanžhot do Olberhau w Niemczech ${ }^{5}$.

\footnotetext{
${ }^{4}$ Wskazuje na to chociażby M. Zaniewicz, O co chodzi z wyrokiem Trybunału Sprawiedliwości UE w sprawie OPAL? [Analiza], Energetyka 24, https://energetyka24.com/o-co-chodzi-z-wyrokiem-trybunalu-sprawiedliwosci-ue-wsopal-analiza (24.12.2019).

5 T. Kubarczyk, M. Żyła, Bezpieczeństwo energetyczne Europy Środkowej $i$ Wschodniej, [w:] red. M. Gębska, M. Kubiak, Współczesne bezpieczeństwo ekonomiczne. Wymiar międzynarodowy, Warszawa 2016, s. 118.
} 


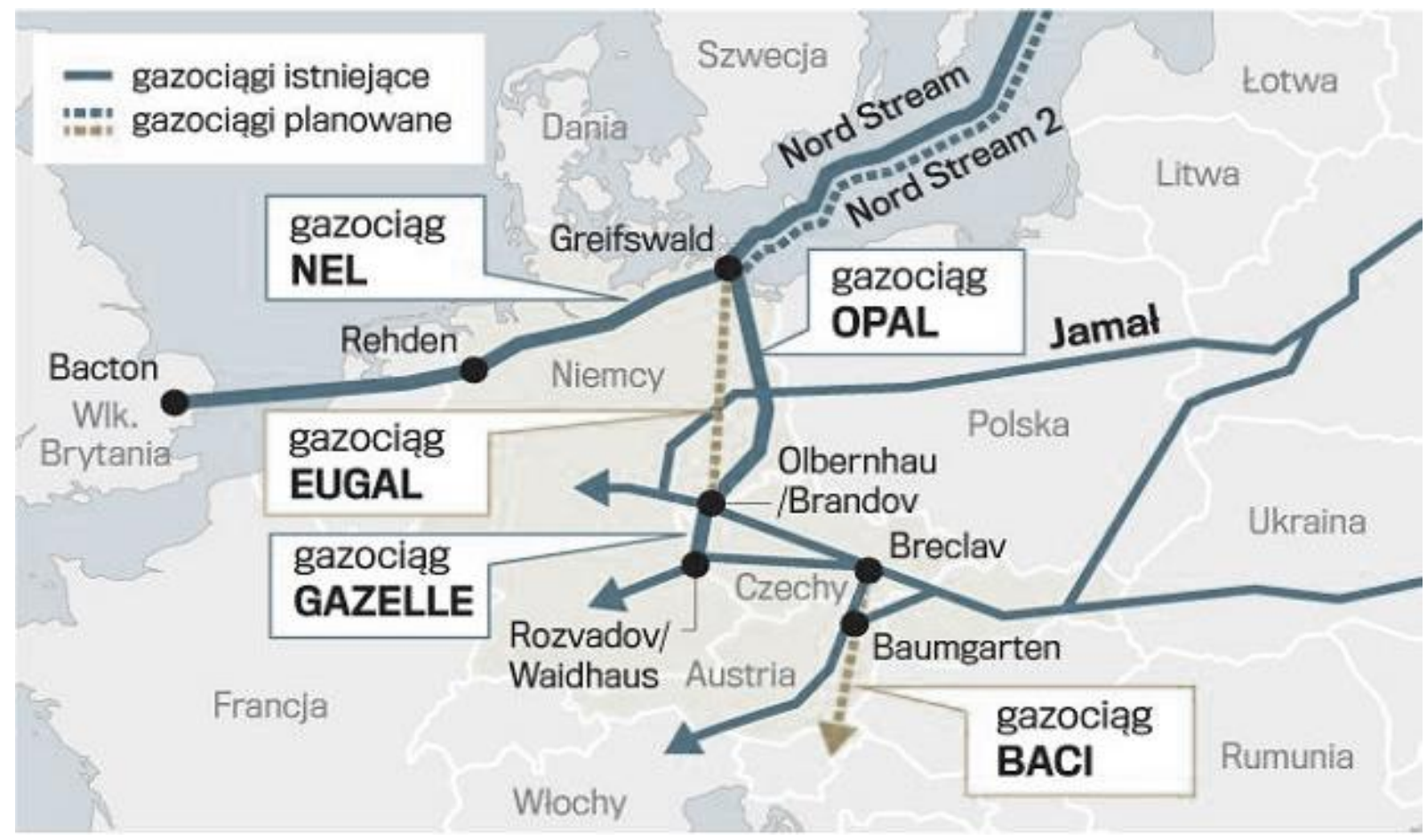

Rysunek 2. Gazociąg NORD STREAM i jego lądowe odnogi

Źródło: A. Kublik, Sukces Polski. Unijny trybunat zatrzymat monopol Gazpromu w gazociagu OPAL, Wyższe wymogi przy imporcie gazu. Czy ceny surowca wzrosna?, Gazeta Wyborcza z dnia 27 grudnia 2016 roku.

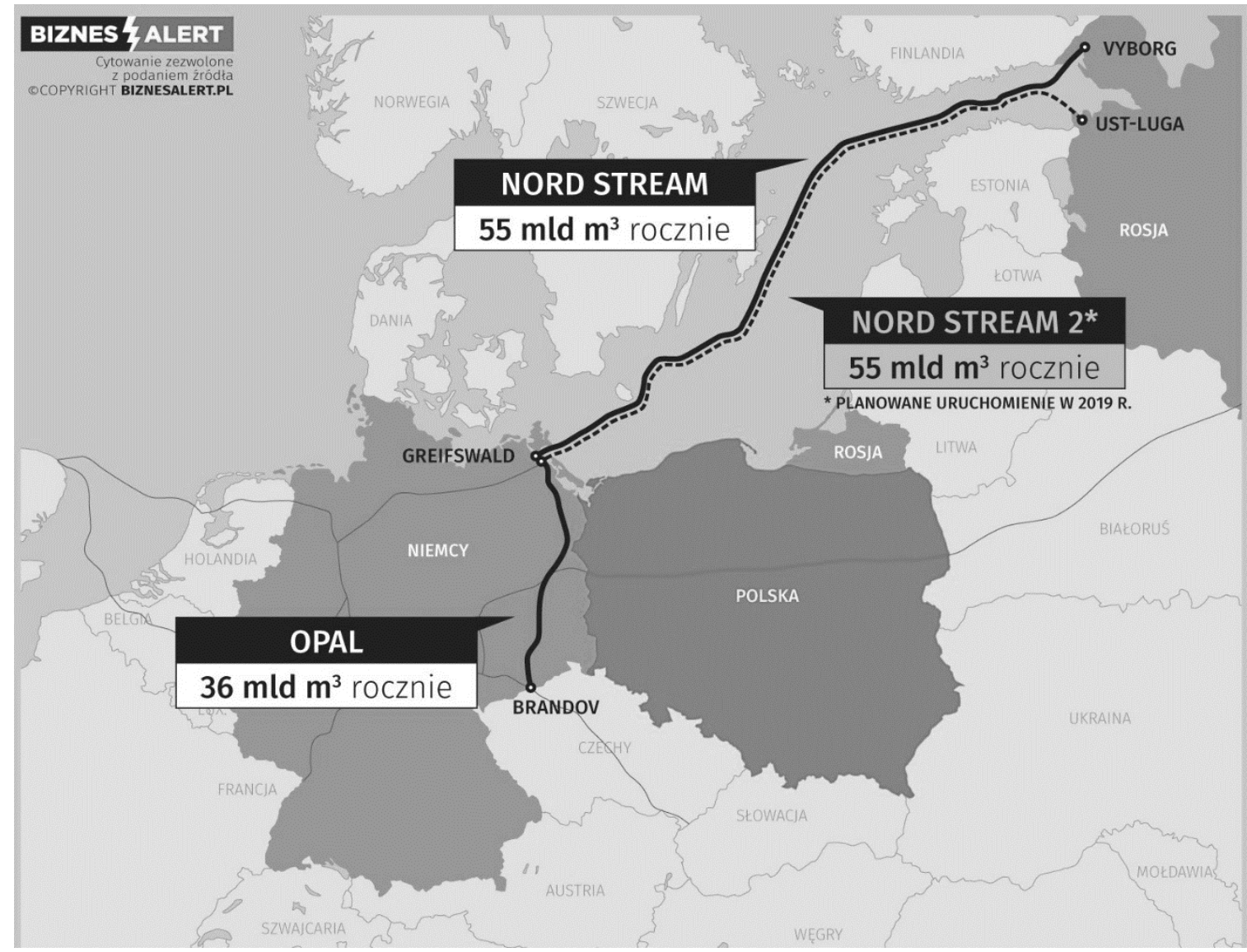

Rysunek 3. Przepustowość gazociągów NORD STREAM oraz OPAL

Źródło: W. Jakóbik, Waszczykowski za szybko grzebie Nord Stream 2,

http://biznesalert.pl/jakobik-waszczykowski-szybko-grzebie-nord-stream-2/. 


\section{MAGISTRALA OPAL JAKO ZAGROŻENIE SYSTEMU ENERGETYCZNEGO REGIONU EUROPY ŚRODKOWO-WSCHODNIEJ}

Pojawiający się $\mathrm{w}$ rozmaitych debatach publicznych, tekstach aktów prawnych ${ }^{6}$ oraz współczesnych pracach naukowych ${ }^{7}$ termin „,bezpieczeństwo energetyczne” może być rozumiany w rozmaity sposób. Uwzględnienie w tej mierze geopolitycznego punktu widzenia prowadzi do wysnucia wniosku, zgodnie z którym bezpieczeństwo energetyczne państwa oznacza jego niezagrożony dostęp do różnych nośników energii ( $\mathrm{w}$ tym także tak istotnego surowca energetycznego, jakim jest gaz ziemny) wraz z zapewnieniem ciągłości ich dostaw. Niezbędne jest tutaj także istnienie dobrze rozwiniętej (odpowiednio rozbudowanej) oraz zdywersyfikowanej sieciowej infrastruktury energetycznej ${ }^{8}$.

Współcześnie pod względem posiadanego poziomu tego bezpieczeństwa poszczególne państwa europejskie znajdują się w nader zróżnicowanym położeniu. Z pewnością istotną rolę odgrywają $\mathrm{w}$ tej mierze historyczne relacje poszczególnych krajów z odbiorcami energii, ich położenie geograficzne czy też przyjęcie i realizowanie narodowych strategii zaopatrzenia w surowce energetyczne.

Wspomniane powyżej zagrożenia powstają nie tylko z uwagi na zwiększenie zależności UE od rosyjskiego surowca, lecz także z powodu utraty znaczenia dotychczasowych potentatów tranzytowych. Towarzyszy temu zwiększenie tranzytowej roli niektórych graczy na europejskim rynku energetycznym (zwłaszcza Czech i Niemiec) ${ }^{9}$, którzy w praktyce zyskują status tak zwanych „hubów” gazowych łączących projekty infrastrukturalne kosztem przede wszystkim Polski oraz Ukrainy. Rosja nie kryje przy tym poszukiwania od 2014 r. alternatywnych dróg przesyłania eksportowanego przez siebie gazu w celu wykluczenia lub zminimalizowania niosącego określone ryzyko transportu surowca przez Ukrainę ${ }^{10}$.

Wielu analityków dostrzega wykorzystanie przez władze Federacji Rosyjskiej znaczenia surowców energetycznych jako niezmiernie ważnego instrumentu polityki zagranicznej tego

\footnotetext{
${ }^{6}$ Na przykład polski ustawodawca w ramach art. 3 pkt 16 ustawy z dnia 10 kwietnia 1997 r. - Prawo energetyczne (tekst jednolity Dz.U.2019 poz.755) definiuje pojęcie bezpieczeństwa energetycznego jako stan gospodarki umożliwiający pokrycie bieżącego i perspektywicznego zapotrzebowania odbiorców na paliwa czy energię w sposób technicznie oraz ekonomicznie uzasadniony (przy zachowaniu wymagań sformułowanych na gruncie prawa ochrony środowiska).

${ }^{7}$ Vide np. przegląd poglądów doktrynalnych, którego dokonał M. Lewandowski, Bezpieczeństwo energetyczne w problematyce bezpieczeństwa narodowego, „De Securitate et Defensione. O Bezpieczeństwie i Obronności”, nr 1(5) 2019, s. 179-182.

${ }^{8}$ B. Nowak, Bezpieczeństwo energetyczne Polski w kontekście bezpieczeństwa energetycznego Unii Europejskiej, [w:] Krytyka prawa. Niezależne studia nad prawem, Tom II, Bezpieczeństwo, red. Nauk. W. Sokolewicz, Warszawa 2010, s. 219.

${ }^{9}$ Niemcy są obecnie największym konsumentem gazu w Europie $\left(80 \mathrm{mld} \mathrm{m}^{3}\right)$ i jednocześnie największym importerem tego surowca z Rosji (50 $\mathrm{mld} \mathrm{m}^{3}$ ). Vide: A. Gawlikowska-Fyk, Nord Stream 2: gazociag podziałów, Infos Nr 13(236), s. 2.

${ }^{10}$ S. Pirani, K. Yafimava, Russian Gas Transit across Ukraine Post-2019: Pipeline Scenarios, Gas Flow Consequences, and Regulatory Constraints, Oxford: Oxford Institute for Energy Studies, February 2016 (OIES Paper, NG 105), https://www.oxfordenergy.org/wpcms/wp-content/uploads/2016/02/Russian-Gas-Transit-Across-Ukraine-Post-2019NG-105.pdf (27.12.2019).
} 
państwa, którego kierownictwo stara się odbudować pozycję mocarstwową i włączyć swój kraj do grona państw decydujących o kształcie ładu międzynarodowego ${ }^{11}$.

Eksperci zwracają też uwagę na kluczowe znaczenie przyznawane kontroli rurociągów i innych urządzeń przesyłowych umiejscowionych na obszarze sąsiednich krajów w rosyjskiej strategii uzależnienia partnerów od tamtejszych dostaw surowców energetycznych ${ }^{12}$. Koresponduje to $\mathrm{z}$ przyznaniem Bałtyckiemu Systemowi Rurociągowemu priorytetowego znaczenia w obowiązującej obecnie strategii energetycznej Rosji ${ }^{13}$.

Niewątpliwie nieskrępowane rygorystycznymi wymogami prawnymi władanie gazociągiem OPAL stanowi istotny instrument integracji ze światowym rynkiem surowców, służy zdobywaniu nowych rynków zbytu czy też sprzyja umacnianiu pozycji na dotychczasowych rynkach eksportowych. Zarazem zwiększa to gwarancje dostaw rosyjskich surowców energetycznych, zabezpiecza stały dopływ dochodów z eksportu oraz wzmacnia pozycję Rosji w negocjacjach $\mathrm{z}$ dotychczasowymi państwami tranzytowymi.

Obszar Europy Środkowej i Wschodniej stanowi szczególnie dogodny teatr oddziaływania polityki surowcowo-energetycznej Federacji Rosyjskiej przede wszystkim z powodu braku wystarczających zasobów bogactw naturalnych umożliwiających państwom regionu osiągnięcie stanu samowystarczalności i suwerenności energetycznej ${ }^{14}$. W dodatku uzależnienie tych krajów od dostaw rosyjskiego „błękitnego paliwa” koresponduje z bliskością geograficzną największego eksportera gazu ziemnego na świecie ${ }^{15}$.

W dodatku w kwestii dostaw surowców energetycznych Rosja jest w Niemczech traktowana jako wiarygodny partner i istotny czynnik wzmacniający bezpieczeństwo zaopatrzenia energetycznego. Z perspektywy Berlina dostawy surowca gazociągami przebiegającymi po dnie Morza Bałtyckiego oraz ich lądowymi przedłużeniami mają określoną wartość nie tylko dla Niemiec, lecz także (w obliczu zmniejszającej się produkcji np. w Holandii) dla Unii Europejskiej (również z uwagi na obniżenie w średniej perspektywie emisji dwutlenku węgla). Wielu przedstawicieli niemieckich elit politycznych i gospodarczych docenia też strategiczne znaczenie

\footnotetext{
${ }^{11} \mathrm{Na}$ temat wykorzystywania geostrategicznego znaczenia surowców energetycznych w polityce prowadzonej przez współczesną Rosję vide zwłaszcza M. Kaszuba, M. Stempień, Surowce energetyczne w polityce Federacji Rosyjskiej, [w:] Polska - Rosja: polityka bezpieczeństwa Federacji Rosyjskiej, red. M. Kaszuba, M. Minkina, Siedlce 2018, s. 79-90 oraz W. Paniuszkin, M. Zygar, Gazprom: rosyjska broń, Warszawa 2008 czy też red. E. Wyciszkiewicz, Geopolityka rurociagów: wspótzależność energetyczna a stosunki międzypaństwowe na obszarze postsowieckim, Warszawa 2008.

12 M. Kaszuba, M. Stempień, op. cit., s. 88.

${ }^{13}$ Bliżej vide np. O. Zakrzewska, Bezpieczeństwo energetyczne w stosunkach Rosja - Unia Europejska w kontekście wspótzależności eksportowo-importowych, „Kwartalnik Kolegium Ekonomiczno-Społecznego. Studia i Prace 2014”, nr 1, s. $153-172$.

${ }^{14} \mathrm{Na}$ temat sytuacji energetycznej tych państw szerzej vide: A. Druszcz, Bezpieczeństwo Europy Środkowo-Wschodniej w kontekście polityki energetycznej Federacji Rosyjskiej [w:] Bezpieczeństwo energetyczne Europy Środkowej, red. P. Mickiewicz, P. Sokołowska, Toruń 2010, s. 119-121.

15 Wynika to przede wszystkim z posiadania największych na globie złóż tego surowca (którego zasoby prawdopodobnie zwiększą się po uzyskaniu dostępu do obszarów arktycznych) oraz stosunkowo konkurencyjnej ceny oferowanej przez tamtejszych dostawców na światowym rynku, a także stosunkowo stabilnych warunków politycznych i ekonomicznych panujących w tym kraju. Vide w szczególności K. Rokiciński, T. Szubrych, Gazociagi podmorskie w polityce bezpieczeństwa energetycznego pótnocnej cześsi Europy Środkowej [w:] Bezpieczeństwo energetyczne Europy Środkowej, red. P. Mickiewicz, P. Sokołowska, Toruń 2010, s. 171.
} 
wzmocnienia pozycji ich kraju jako centrum dystrybucji rosyjskiego gazu ziemnego w ramach Unii Europejskiej, z którego usług będą również korzystały kraje powiązane gazociągiem „Sojuz”16.

$\mathrm{Z}$ drugiej strony realizacja szeroko zakrojonej energetycznej współpracy niemiecko-rosyjskiej obciąża stosunki Niemiec $\mathrm{z}$ państwami regionu Europy Środkowo-Wschodniej ${ }^{17} \mathrm{i}$ to przede wszystkim z powodów ekonomicznych i geopolitycznych. Tamtejsze elity polityczne i gospodarcze zdają sobie bowiem doskonale sprawę $\mathrm{z}$ tego, że dominacja Rosji w europejskim sektorze energetycznym stwarza fundamentalne zagrożenie dla ich interesów i to nie tylko w sferze zachowania zabezpieczenia dostaw surowców energetycznych. $Z$ niepokojem spoglądają więc na praktyki monopolistyczne koncernu Gazprom wiążąc te działania z przejawianymi przez władze Federacji Rosyjskiej hegemonicznymi tendencjami politycznymi, które wydają się zmierzać do odtworzenia strefy rosyjskich wpływów na całym obszarze postradzieckiego imperium.

\section{Polityka BeZPIECZEŃSTWA ENERGETYCZNEgo PAŃSTWA POLSKIEgo WOBEC GAZOCIĄGU OPAL}

W przeciwieństwie do magistrali NORD STREAM 1 jego lądowe przedłużenie podlega w całej rozciągłości przepisom UE dotyczącym infrastruktury przesyłowej. Oznacza to, że zgodnie z tzw. regułą dostępu stron trzecich Gazprom miał prawo korzystać jedynie z około połowy przepustowości gazociągu OPAL ${ }^{18}$.

Wyjątkowe, uprzywilejowane traktowanie przez władze niemieckie oraz Komisję Europejską rosyjskiego koncernu gazowego stanowi odstępstwo od reguł unijnego prawodawstwa zmierzającego do liberalizacji europejskiego rynku energetycznego. Utrzymywanie tego typu praktyk groziło wzmocnieniem i tak silnej (właściwie monopolistycznej) pozycji Gazpromu (mogącemu narzucić odbiorcom wysokie ceny na dobro powszechnego użytku, jakim jest gaz), mogło zaburzyć konkurencję na rynku energetycznym czy też pogorszyć ekonomiczną kondycję konkurentów rosyjskiego operatora surowcowego. Rodziło to określone ryzyka dla kondycji właściwie całej polskiej gospodarki czy też konkurencyjności wyrobów wytwarzanych w wielu branżach (co może mieć szczególnie niekorzystny wpływ np. na produkcję nawozów) bądź nastrojów rodzimych konsumentów.

\footnotetext{
${ }^{16}$ Bliżej na ten temat vide B. Molo, Główne kontrowersje wokół budowy gazociagu Nord Stream 2, „Krakowskie Studia Międzynarodowe", nr 4 (XV), 2018 nr 2, s. 53-65 czy też M. Paszyn, Gazprom na niemieckim rynku energetycznym w okresie rząó́w Angeli Merkel 2005-2014, ,Studia Niemcoznawcze”, T. 55 (2015), s. 322 i n.

${ }^{17} \mathrm{~W}$ listopadzie 2019 r. Bundestag przyjął nowelizację ustawy o zaopatrzeniu w energię elektryczną i gaz, która stanowi implementację nowej dyrektywy gazowej UE (dotyczącej m.in. Gazpromu i magistrali Nord Stream 2). Towarzyszyły temu zapewnienia, że Niemcy bardzo poważnie traktują obawy wschodnich partnerów (Polski i państw bałtyckich) o stan ich bezpieczeństwa energetycznego. Vide: Bundestag przyjąt unijna dyrektywe gazowa, https://www.pb.pl/ bundestag-przyjal-unijna-dyrektywe-gazowa-975282 (28.12.2019).

${ }^{18}$ Przed 2016 rokiem rurociąg OPAL został zwolniony ze stosowania zasad Trzeciego Pakietu Energetycznego do wspomnianego poziomu 50\% (z uwagi na trudności z realizacją obietnicy programu uwolnienia gazu).Vide szerzej: Komisja Europejska: $C f$ the European Commission's decision of 2009: https://ec.europa.eu/energy/sites/ener/files/ documents/2009_opal_decision_de.pdf (26.12.2019).
} 
Nie może więc dziwić stanowcza reakcja władz polskich oraz zarządu rodzimego, wiodącego dostawcy gazu ziemnego, jakim jest Polskie Górnictwo Naftowe i Gazownictwo Spółka Akcyjna, oraz jego ukraińskiego odpowiednika - koncernu Naftohaz.

Inicjatorem tych poczynań była spółka PGNiG Supply \& Trading GmbH (podmiot zależny w grupie kapitałowej Polskiego Górnictwa Naftowego i Gazownictwa), która 28 listopada 2016 r. zaskarżyła do Trybunału Sprawiedliwości Unii Europejskiej decyzję Komisji Europejskiej zwalniającą gazociąg OPAL z zasady nieskrępowanego dostępu stron trzecich do infrastruktury przesyłowej położonej na terenie Unii Europejskiej ${ }^{19}$.

Przedstawiciele prawni tej spółki złożyli jednocześnie do Trybunału wniosek o pilne wstrzymanie wykonania umowy pomiędzy Bundesnetzagentur (niemieckim regulatorem rynku energii), Opal GmbH, Gazpromem i Gazpromem Eksport, która zwalnia z obowiązku zapewnienia swobodnego dostępu strony trzeciej do przesyłania gazu. W sumie w skardze złożonej do Trybunału Sprawiedliwości Unii Europejskiej (TSUE) PGNiG Supply \& Trading GmbH postawił Komisji Europejskiej 14 zarzutów dotyczących złamania przez Komisję Europejską reguł unijnego prawa w związku z wydaniem decyzji w sprawie gazociągu OPAL. Wspomniane zarzuty w szczególności dotyczą kierowania się dyskryminacyjnymi przesłankami i naruszenia wspólnotowych zasad respektowania konkurencji na europejskim rynku gazu oraz złamania traktatowych zasad pewności prawa, ochrony interesów podmiotów trzecich oraz proporcjonalności, a także przepisów zawartej pomiędzy Unią Europejską a Ukrainą umowy stowarzyszeniowej ${ }^{20}$.

Podobną skargę powód skierował w tym samym czasie w stosunku do rozstrzygnięć w sprawie magistrali OPAL podjętych przez niemiecki organ regulacyjny na rynku energii (tj. Bundesnetzagentur ${ }^{21}$ do niemieckiego Wyższego Sądu Krajowego w Dusseldorfie, który już w dniu 16 grudnia 2016 r. zakazał wykonywania decyzji KE o zwiększeniu dostępu Gazpromu do niemieckiej infrastruktury gazowej ${ }^{22}$. W rezultacie podjęcia tej decyzji Niemcy nie mogli organizować nowych aukcji na przepustowość gazociągu OPAL.

Niezależnie od wspomnianych kroków prawnych również polski rząd ${ }^{23} \mathrm{w}$ dniu 16 grudnia 2016 r. skierował do TSUE własną skargę, w której wskazano na wzmacnianie przez Komisję Europejską w praktyce monopolistycznej pozycji Gazpromu i prowadzenie do uzależnienia się od jednego (pochodzącego z Rosji) źródła dostaw. W opinii polskich władz ma to pozostawać

\footnotetext{
${ }^{19}$ Przywołana decyzja miała wejść w życie w dniu 31 grudnia 2016 r. Szerzej na temat wspomnianego, unijnego pakietu energetycznego (na który składają się dwie dyrektywy rynkowe - Dyrektywa Parlamentu Europejskiego i Rady Europy 2009/73/WE z dnia 13 lipca $2009 \mathrm{r}$., a ponadto dwa rozporządzenia przesyłowe oraz rozporządzenie ustanawiające Agencję ds. współpracy Organów Regulacji Energetyki) vide: https://www.ure.gov.pl/pl/urzad/wspolpraca-miedzynar od/2579,Trz eci-pakiet-energetyczny-w-Parlamencie-Europejskim.html (strona Urzędu Regulacji Energetyki). Vide również L. Olejarz, Trzeci Pakiet Energetyczny: szansa na uniknięcie kolejnego kryzysu gazowego?, Częśc 1, „Przegląd PrawnoEkonomiczny” 2011, nr 1, s.75-83 oraz Część 2, ,Przegląd Prawno-Ekonomiczny” 2011, nr 3, s. 93-105.

20 Vide: strona www Polskiego Górnictwa Naftowego i Gazownictwa: http://www.pgnig.pl/aktualnosci/-/newslist/id/pgnig-14-zarzutow-wobec-komisji-europejskiej-w-sprawie-opal/newsGroupId/10184?changeYear=2016 \&currentPage=1 (niżej cytowane jako: PGNiG) (28.12.2019).

${ }^{21}$ Chodzi tu o porozumienie zawarte w maju 2016 r. pomiędzy Bnetza, Gazpromem, Gazpromem Export i operatorem gazociągu (OPAL Gastransport) w sprawie zwolnienia z zasady dostępu stron trzecich do przepustowości gazociągu.

${ }^{22}$ Vide szerzej S. Zaręba, Aktualna sytuacja prawna gazociagu OPAL, „Biuletyn PISM”, nr 9 (1451), 26 stycznia 2017 r.

${ }^{23}$ Postępowanie prowadził zespół prawników reprezentujących Ministerstwa Energii oraz Spraw Zagranicznych.
} 
w „oczywistej sprzeczności” z zasadą dywersyfikacji bądź z postanowieniami unijnej dyrektywy dotyczącej wspólnego rynku gazu. Opisywane postępowanie w konsekwencji rodzi określone zagrożenia dla funkcjonowania europejskiej solidarności energetycznej oraz dla bezpieczeństwa dostaw gazu w UE (a w szczególności w regionie Europy Środkowej) ${ }^{24}$.

Jednocześnie polska strona podjęła na arenie dyplomatycznej działania zmierzające do powstrzymania ekspansji rosyjskiego koncernu Gazprom i zwiększenia szans na korzystne dla Polski rozstrzygnięcie sporu z Komisją Europejską. Chcąc podkreślić, że sprawa magistrali OPAL ma istotne znaczenie również dla stabilności energetycznej i geopolitycznej innych wywodzących się $\mathrm{z}$ naszego regionu państw członkowskich Unii Europejskiej, Ministerstwo Spraw Zagranicznych skłoniło rządy Litwy i Łotwy do przyłączenia się do wspomnianej skargi na decyzję KE pod koniec marca 2017 r. $^{25}$

W przypadku strony ukraińskiej natomiast - poza wspomnianymi zagrożeniami dla kondycji Naftohazu (obecnie największego płatnika do krajowego budżetu) ${ }^{26}$ - zasadniczym motywem podjętych działań były obawy o pogorszenie sytuacji finansowej państwa z tytułu zmniejszenia opłat tranzytowych czerpanych za przesyłanie rosyjskiego gazu do Europy. Powodowani tego typu motywami przedstawiciele Naftohazu w marcu 2017 r. złożyli pozew przeciwko Komisji Europejskiej do Trybunału Sprawiedliwości Unii Europejskiej w Luksemburgu ${ }^{27}$. Do zarzutów zaliczyć trzeba naruszenie wspomnianej umowy stowarzyszeniowej pomiędzy Ukrainą a Unią Europejską ${ }^{28}$, pogorszenie pozycji konkurencyjnej Naftohazu oraz zagrożenie stabilności dostaw gazu bądź wpływów do budżetu państwa ukraińskiego (rocznie rzędu 290-320 mln dolarów) z tytułu wnoszonych dotychczas opłat tranzytowych ${ }^{29}$.

\footnotetext{
${ }^{24}$ Polski rząd zaskarżyt do Trybunatu UE decyzje KE ws. OPAL, http://www.radiomaryja.pl/informacje/polskainformacje/polski-rzad-zaskarzyl-trybunalu-ue-decyzje-ke-ws-opalu/ (27.12. 2019).

${ }^{25}$ MSZ: Litwa i Lotwa przytaczyly się do polskiej skargi do TSUE ws. Opalu, https://www.kierunekchemia.pl/ artykul,36868,msz-litwa-i-lotwa-przylaczyly-sie-do-polskiej-skargi-do-tsue-ws-opalu.html (28.12. 2019).

${ }^{26}$ Vide: A. Gawlikowska-Fyk, op. cit., s. 3.

${ }^{27}$ Vide szerzej argumentację zamieszczoną na oficjalnej stronie internetowej Naftohazu: http://www.naftogaz.com/ www/3/nakweben.nsf/0/FF8BE665665F161CC22580D600655C50?OpenDocument\&year=2017\&month=03\&nt=Ne ws\&, (26.12.2019). Władze tego koncernu przyznają, że jest to działanie podjęte w ślad za inicjatywą przejawioną w tej sprawie przez PGNiG, zaś uzyskanie dostępu do toczącego się sporu zmierza do przedstawienia dodatkowych argumentów ze strony ukraińskiej.

28 Art. 274 Układu przewiduje wzajemne uwzględnianie przez strony możliwości i potencjału infrastruktury energetycznej. Por.: Układ o stowarzyszeniu między Unią Europejską i Europejską Wspólnotą Energii Atomowej oraz ich państwami członkowskimi z jednej strony, a Ukrainą z drugiej strony (Dz.U. L 161 z 29.5.2014).

${ }^{29}$ I. Trusewicz, Ukraina pozywa Unię za OPAL, „Rzeczpospolita” z dnia 30 marca 2017 r. Z kolei Ł. Wojcieszak podkreśla, że większa część eksportowanego do Europy „błękitnego paliwa” jest przesyłana za pośrednictwem ukraińskich magistrali energetycznych (Ł. Wojcieszak, Polska, Ukraina, Białoruś wobec problemu dostaw i tranzytu rosyjskiego gazu, Bielsko-Biała 2013, s. 172). Warto dodać, że Ukraina w wyniku polityki gospodarczej i energetycznej b. ZSRR dysponuje obecnie największą siecią gazociągów i podziemnych zbiorników gazu w całej Europie, co niewątpliwie utrudnia stronie rosyjskiej uzyskanie energetycznej hegemonii na kontynencie europejskim.
} 


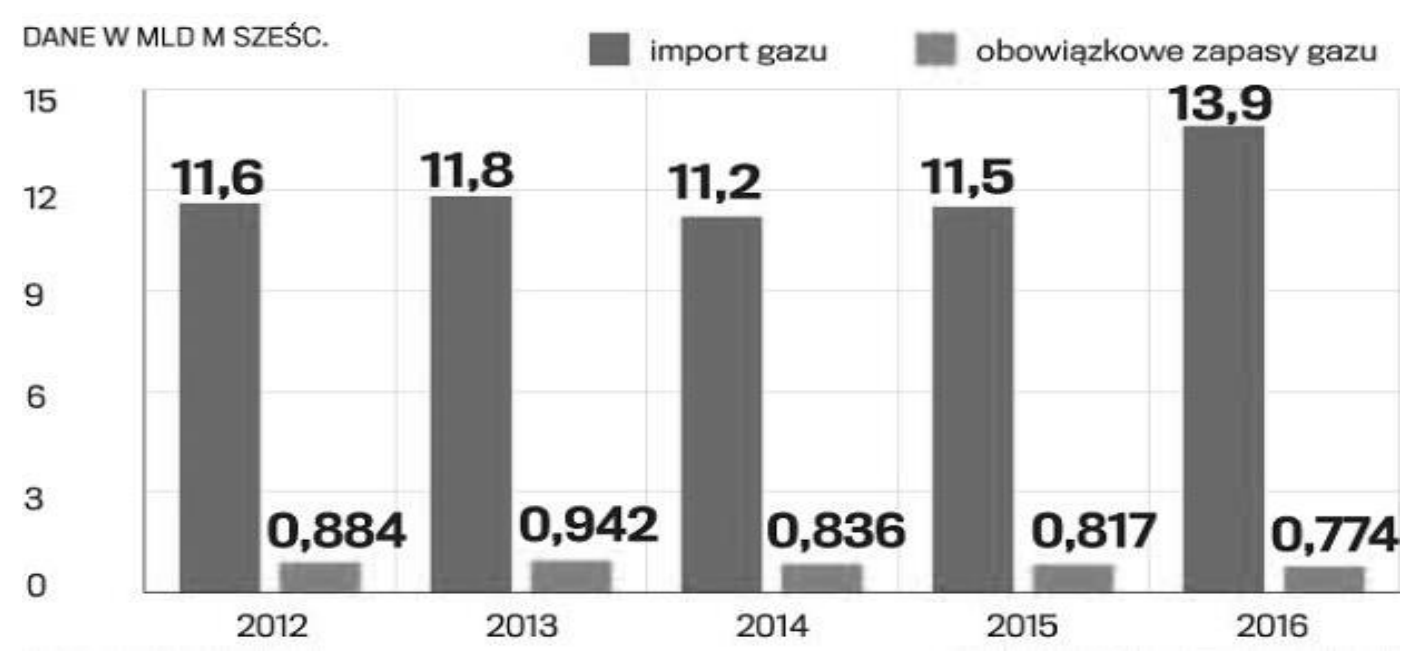

Rysunek 4. Import gazu do Polski i obowiązkowe zapasy

Źródło: Ministerstwo Energii, cyt. za: A. Kublik, Wyższe wymogi przy imporcie gazu.

Czy ceny surowca wzrosna?, „Gazeta Wyborcza” z dnia 10 sierpnia 2017 roku.

Należy podkreślić, że podmioty skarżące wystąpiły z wnioskiem o wstrzymanie wykonalności decyzji Komisji Europejskiej do momentu wydania przez TSUE wyroku co do istoty sprawy. Uznały bowiem, że zwiększenie przez Rosjan możliwości przesyłowych magistrali OPAL prowadzić będzie do zmniejszenia transportu „błękitnego” paliwa z Rosji do Europy Środkowej i Zachodniej za pomocą gazociągów Jamał-Europa i Braterstwo, przez co mogłyby powstać określone zagrożenia dla bezpieczeństwa energetycznego państw skarżących ${ }^{30}$. Jednakże postanowieniem z 21 lipca 2017 r. prezes TSUE zarządził oddalenie tego wniosku z uwagi na brak wystarczających podstaw dowodowych w tej mierze. ${ }^{31}$

Bardzo istotną rolę dla bezpieczeństwa energetycznego państw naszego regionu wydaje się odgrywać korzystny dla strony skarżącej wyrok Trybunał Sprawiedliwości Unii Europejskiej z dnia 10 września 2019 r. w sprawie korzystania przez Gazprom z Gazociągu OPAL. Trybunał wskazał bowiem, że zaskarżona decyzja KE została wydana z naruszeniem sformułowanej w art. 194 ust. 1 Traktatu o funkcjonowaniu Unii Europejskiej (TFUE) ${ }^{32}$ zasady solidarności energetycznej ${ }^{33}$.

Wprawdzie jednocześnie TSUE zaznaczył, że stosowanie zasady solidarności energetycznej nie oznacza, by polityka Unii w dziedzinie energetyki nie mogła w żadnym wypadku mieć negatywnych skutków dla szczególnych interesów danego państwa członkowskiego w dziedzinie

\footnotetext{
${ }^{30}$ Sąd Unii Europejskiej, Komunikat prasowy nr 83/17 Luksemburg, 21 lipca 2017 r. https://curia.europa.eu/ $\mathrm{jcms/upload/docs/application/pdf/2017-07/cp170083pl.pdf} \mathrm{(25.12.} \mathrm{2019).}$

31 J. Faszcza, Studium przypadku OPAL: wybrane aspekty decyzji zwalniajacej infrastrukturę ze stosowania zasad trzeciego pakietu energetycznego, na przykładzie gazociagu OPAL, „Krytyka Prawa”, tom 9, nr 4/2017, s. 63-64.

${ }^{32}$ Pelny tekst art. 194 ust. 1 TFUE brzmi: „1.W ramach ustanawiania lub funkcjonowania rynku wewnętrznego oraz z uwzględnieniem potrzeby zachowania i poprawy stanu środowiska, polityka Unii w dziedzinie energetyki ma na celu, w duchu solidarności między Państwami Członkowskimi: a) zapewnienie funkcjonowania rynku energii; b) zapewnienie bezpieczeństwa dostaw energii w Unii; c) wspieranie efektywności energetycznej i oszczędności energii, jak również rozwoju nowych i odnawialnych form energii; oraz d) wspieranie wzajemnych połączeń między sieciami energii”. Vide: Traktat o Funkcjonowaniu Unii Europejskiej (Dz.U.2004.90.864/2).

${ }^{33}$ Wyrok Sądu (dawniej: Sądu Pierwszej Instancji) z dnia 10 września 2019 r. T-883/16 https://sip.lex.pl/ orzeczenia-i-pisma-urzedowe/orzeczenia-sadow/t-883-16-rzeczpospolita-polska-przeciwko-komisji-522810995 (27.12. 2019).
} 
energetyki. Tym niemniej jednak instytucje Unii i państwa członkowskie są w ramach stosowania tej polityki zobowiązane uwzględniać zarówno interesy Unii, jak i poszczególnych państw członkowskich oraz wyważać je w przypadku powstawania sprzeczności ${ }^{34}$.

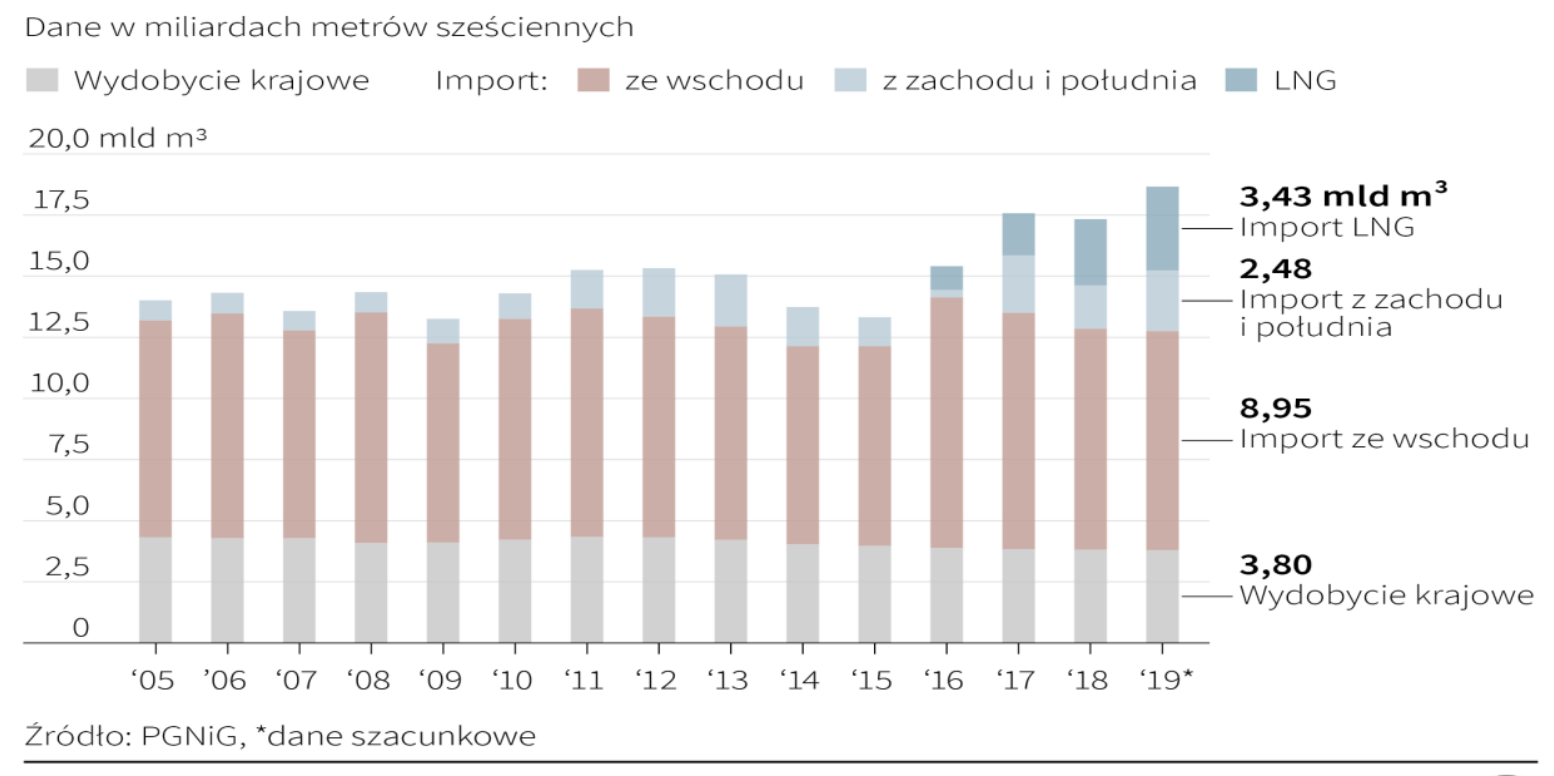

(Pap

Rysunek 5. Źródła pozyskania gazu ziemnego dla Polski

Źródło: Gaz coraz tańszy: ceny prawie o 1/5 niższe niż pięć lat temu, „Radio Zachód”, publikacja z dnia 23.06.2020, https://www.zachod.p1/203264/gaz-coraz-tanszy-ceny-prawie-o-1-5-nizsze-niz-piec-lat-temu/.

Trybunał Sprawiedliwości Unii Europejskiej zarzucił także Komisji w szczególności brak szerszego zbadania tego, czy zaskarżona decyzja narusza zasadę bezpieczeństwa energetycznego oraz zasadę solidarności energetycznej, w tym zwłaszcza dla polityki Rzeczypospolitej Polskiej w dziedzinie energetyki z uwagi na przekierowania na trasę tranzytu Nord Stream 1 oraz OPAL części gazu ziemnego przesyłanego uprzednio gazociągami Jamał i Braterstwo. Tymczasem zarówno Unia, jak i państwa członkowskie w ramach wykonywania kompetencji związanych ze wspólną polityką energetyczną są obowiązane starać się unikać podejmowania środków mogących naruszać interesy Unii i pozostałych państw członkowskich w zakresie bezpieczeństwa dostaw, ich efektywności gospodarczej i politycznej oraz dywersyfikacji źródeł zaopatrzenia lub dostaw. $\mathrm{W}$ ramach prowadzenia wspólnotowej polityki istotne jest wreszcie zaakceptowanie faktycznej współzależności i solidarności europejskich partnerów ${ }^{35}$.

Należy tutaj dodać, iż od wielu lat bezpieczeństwo energetyczne stanowi jeden z priorytetów polityki energetycznej Unii Europejskiej, co znalazło wyraz w wielu wspólnotowych aktach

\footnotetext{
${ }^{34}$ Ibidem.

35 Ibidem.
} 
prawnych $^{36}$ i dokumentach programowo-politycznych ${ }^{37}$. Analiza tych źródeł może prowadzić do wysnucia argumentów na rzecz przyjęcia tezy o niezgodności decyzji KE z dnia 26 października 2016 r. w sprawie gazociągu OPAL z regułami mającymi porządkować funkcjonowanie unijnego rynku energii, który co do zasady ma podlegać procesowi liberalizacji oraz powinien zostać otwarty na funkcjonowanie wolnej konkurencji ${ }^{38}$.

\section{Podsumowanie}

O ile współcześnie właściwie każde państwo jest w stanie wyprodukować energię elektryczną, o tyle tylko nieliczne $\mathrm{z}$ nich posiadają na swoich terytoriach złoża gazu w ilości umożliwiającej swobodny eksport tych zasobów. Strategiczne znaczenie gazu dla kreowania rozwoju gospodarczego i funkcjonowania współczesnych społeczeństw nie podlega dyskusji i sprawia, że jego dostawy należy rozpatrywać nie tylko w ramach ekonomicznych uwarunkowań wzajemnej gry popytu i podaży, ale również w kategoriach geopolitycznych oraz kwestiach dotyczących bezpieczeństwa państwa. Rozpatrując zagadnienia dotyczące pojęcia bezpieczeństwa energetycznego w sektorze gazowym istotne jest także wskazanie na konieczność wprowadzania przez państwa odpowiednich regulacji prawnych dla budowy bezpieczeństwa wewnętrznego rynku gazu.

Należy więc uznać, że w dobie obecnej coraz częściej surowce energetyczne oraz ich niezakłócone przesyłanie stanowi ważny element zarówno bezpieczeństwa narodowego, jak i stabilizacji ekonomicznej stając się przy tym przedmiotem międzynarodowej rywalizacji oraz istotnym zarzewiem konfliktów.

Spektakularny przykład stanowi strategia energetyczna Federacji Rosyjskiej, która od dawna jest stosowana przez to państwo jako podstawowe narzędzie aktualnej polityki zagranicznej. Istotne jest tutaj zwrócenie uwagi na wykorzystanie koncernu Gazprom jako wiodącego aktora w prowadzonej przez to Rosję grze geopolitycznej. W przypadku gazociągu OPAL sensem wdrażanej przez Federację Rosyjską strategii energetycznej jest niewątpliwie zawładnięcie przez Gazprom omawianą magistralą przesyłową jako strategicznym łącznikiem z istniejącą na terenie Europy siecią infrastruktury gazowej. W tym celu strona rosyjska dąży konsekwentnie od wielu lat do zwolnienia tego koncernu z respektowania wymogów nałożonych przez prawo unijne, które zmierzają do dywersyfikacji źródeł i tras dostaw surowców energetycznych.

Zaprezentowane w niniejszym artykule działanie KE i władz niemieckich wydają się podważać dążenia do zwiększenie odporności całej Unii Europejskiej na zakłócenia w dostawach gazu. Rozszerzenie przywilejów Gazpromu rodzi realne ryzyko uzyskania przez ten koncern

\footnotetext{
${ }^{36}$ Należy przywołać zwłaszcza art. 176 Traktatu Lizbońskiego, który mówi o europejskiej solidarności energetycznej oraz o zapewnieniu bezpieczeństwa dostaw energii w Unii (Dz. U. UE, C 306 z 17.12.2007). Na mocy tego przepisu władze unijne uzyskała formalne kompetencje do prowadzenia polityki energetycznej na szczeblu wspólnotowym.

${ }^{37}$ Vide w tej mierze chociażby: I. Kraś, Bezpieczeństwo energetyczne Unii Europejskiej, „Prace Naukowe Akademii im. Jana Długosza w Częstochowie. Res Politicae", T. 4 (2011), s. 35 i n.

${ }^{38} \mathrm{~W}$ polskiej literaturze przedmiotu najbardziej wyczerpującą analizę tych zagadnień przeprowadził J. Faszcza, Studium przypadku OPAL: wybrane aspekty decyzji zwalniającj infrastrukturę ze stosowania zasad trzeciego pakietu energetycznego, na przykladzie gazociagu OPAL, „Krytyka Prawa”, tom 9, nr 4/2017, s. 56-77.
} 
monopolistycznej pozycji w dystrybuowaniu rosyjskiego „błękitnego paliwa” do większości państw członkowskich Unii Europejskiej (a zwłaszcza regionu Europy Środkowo-Wschodniej). Dodatkowo w ramach wspólnoty europejskiej wydaje się wzrastać pozycja Niemiec jako gazowego gracza $\mathrm{nr} 1$ wraz z jednoczesnym, istotnym osłabieniem znaczenia Polski oraz Ukrainy jako strategicznych (do tej pory) terytoriów tranzytowych rosyjskich surowców energetycznych.

Nie może więc dziwić stanowcza reakcja ukraińskich czy nadbałtyckich kręgów decyzyjnych i uznanie budowy gazociągu OPAL czy decyzji Komisji Europejskiej o oddaniu go we władanie rosyjskiemu Gazpromowi za ogromne wyzwanie dla stabilności energetycznej i geopolitycznej całego regionu. Obawy te były tak silne, że wbrew dotychczasowej praktyce indywidualnego załatwiania własnych problemów energetycznych na drodze bilateralnych porozumień ze stroną rosyjską tym razem zdecydowano się na podjęcie wspólnych, solidarnych działań w ramach unijnego systemu prawno-instytucjonalnego.

Podejście to okazało się właściwe, gdyż Trybunał Sprawiedliwości Unii Europejskiej w Luksemburgu w 2019 roku w sprawie korzystania przez Gazprom z gazociągu OPAL uznał, że zaskarżona decyzja KE została wydana z naruszeniem traktatowej zasady solidarności energetycznej. Zainicjowane przez Polskę wystąpienie na forum międzynarodowym w udany sposób zmierza do utrzymania wschodnioeuropejskiej suwerenności energetycznej oraz do przeciwdziałania utrwaleniu stanu zależności surowcowej od potężnego wschodniego sąsiada.

Ponieważ niewątpliwie niektóre państwa członkowskie (takie jak Polska) mają słabą pozycję w negocjacjach z Rosją, stąd w przyszłości Komisja Europejska powinna je wspierać w dwustronnych negocjacjach poprzez ukierunkowane działania nie zagrażając jednocześnie bezpieczeństwu dostaw w całej Unii Europejskiej. Równie istotny wydają się być wspólne działania państw naszego regionu zorientowane na tworzenie wspólnotowych regulacji prawnych zmierzających do utrzymania konkurencji na rynku gazu, a potem także monitorowanie wdrażania tych reguł w praktyce.

\section{BIBLIOGRAFIA}

\section{MONOGRAFIE I OPRACOWANIA}

Paniuszkin Walerij, Zygar Michaił. 2008. Gazprom: rosyjska broń. Warszawa: Wydawnictwo WAB.

Wojcieszak Łukasz, Polska. 2013. Ukraina, Białoruś wobec problemu dostaw i tranzytu rosyjskiego gazu. Bielsko-Biała: Wyższa Szkoła Administracji.

Wyciszkiewicz Ernest. 2008. Geopolityka rurociągów: współzależność energetyczna a stosunki międzypaństwowe na obszarze postsowieckim. Warszawa: Polski Instytut Spraw Międzynarodowych.

\section{ARTYKULY}

Faszcza Jakub. 2017. „Studium przypadku OPAL: wybrane aspekty decyzji zwalniającej infrastrukturę ze stosowania zasad trzeciego pakietu energetycznego, na przykładzie gazociągu OPAL.” Krytyka Prawa tom 9 nr 4: 56-77. 
Gawlikowska-Fyk Aleksandra. 2017. „Nord Stream 2: gazociąg podziałów” Infos 13(236): 1-4.

Kraś Ireneusz. 2011. Bezpieczeństwo energetyczne Unii Europejskiej, [w:] „Prace Naukowe Akademii im. Jana Długosza w Częstochowie. Res Politicae", T. 4, 35-48.

Lewandowski Mateusz. 2019. „Bezpieczeństwo energetyczne w problematyce bezpieczeństwa narodowego" De securitate et defensione. O bezpieczeństwie i obronności 1(5): 168-185.

Molo Beata. 2018. Główne kontrowersje wokół budowy gazociągu Nord Stream 2". Krakowskie Studia Międzynarodowe 4 (XV) nr 2: 53-65.

Olejarz Lucyna. 2011. „Trzeci Pakiet Energetyczny: szansa na uniknięcie kolejnego kryzysu gazowego? Część 1" Przegląd Prawno-Ekonomiczny nr 1: 75-83.

Olejarz Lucyna. 2011. „Trzeci Pakiet Energetyczny: szansa na uniknięcie kolejnego kryzysu gazowego?, Część 2" Przegląd Prawno-Ekonomiczny nr 3: 93-105.

Paszyn Maciej. 2015. „Gazprom na niemieckim rynku energetycznym w okresie rządów Angeli Merkel 2005-2014" Studia Niemcoznawcze T. 55: 321-336.

Trusewicz Iwona, 2017. „Ukraina pozywa Unię za OPAL” Rzeczpospolita z dnia 30 marca.

Zakrzewska Olga. 2014. „Bezpieczeństwo energetyczne w stosunkach Rosja - Unia Europejska w kontekście współzależności eksportowo-importowych" Kwartalnik Kolegium Ekonomiczno-Społecznego. Studia i Prace nr 1" 153-172.

Zaręba Szymon. 2017. „Aktualna sytuacja prawna gazociągu OPAL” Biuletyn PISM nr 9 (1451), 26 stycznia.

\section{ROZDZIALY}

Druszcz Anna. 2010. Bezpieczeństwo Europy Środkowo-Wschodniej w kontekście polityki energetycznej, Federacji Rosyjskiej, [w:] Bezpieczeństwo energetyczne Europy Środkowej, red. Piotr Mickiewicz, Patrycja Sokołowska, Wydawnictwo Adam Marszałek, Toruń, 119-121.

Kaszuba Malina, Stempień Marta. 2018. Surowce energetyczne w polityce Federacji Rosyjskiej, [w:] Polska - Rosja: polityka bezpieczeństwa Federacji Rosyjskiej, red. Kaszuba Malina, Minkina Mirosław, Uniwersytet Humanistyczno-Przyrodniczy w Siedlcach, Siedlce, 79-90.

Kubarczyk Tadeusz, Żyła Marek. 2016. Bezpieczeństwo energetyczne Europy Środkowej i Wschodniej, [w:] Współczesne bezpieczeństwo ekonomiczne. Wymiar międzynarodowy, red. Gębska Marta, Kubiak Mariusz, Akademia Sztuki Wojennej, Warszawa.

Nowak Bartłomiej. 2010. Bezpieczeństwo energetyczne Polski w kontekście bezpieczeństwa energetycznego Unii Europejskiej, [w:] Krytyka prawa. Niezależne studia nad prawem, Tom II. Bezpieczeństwo, red. Sokolewicz Wiesław, Akademia Leona Koźmińskiego, Warszawa, 219-237.

Rokiciński Krzysztof, Szubrych Tomasz. 2010. Gazociągi podmorskie w polityce bezpieczeństwa energetycznego północnej części Europy Środkowej [w:] Bezpieczeństwo energetyczne Europy Środkowej, red. Mickiewicz Piotr, Sokołowska Patrycja, Wydawnictwo Adam Marszałek, Toruń, 171. 


\section{ŹRÓDLA INTERNETOWE}

Analyse: Exportoptionen für russisches Erdgas nach dem Scheitern von South Stream, http://www.bpb.de/internationales/europa/russland/analysen/214481/analyseexportoptionen-fuer-russisches-erdgas-nach-dem-scheitern-von-south-stream.

Andrzej Kublik. 2016. Sukces Polski. Unijny trybunał zatrzymał monopol Gazpromu w gazociągu OPAL, Wyższe wymogi przy imporcie gazu. Czy ceny surowca wzrosną?, „Gazeta Wyborcza” z dnia 27 grudnia, https://wyborcza.biz/biznes/1,100896,2117199 0,sukces-pgnig-unijny-trybunal-kwestionuje-monopol-gazpromu-na.html.

Andrzej Kublik. 2017. Wyższe wymogi przy imporcie gazu. Czy ceny surowca wzrosną?, „Gazeta Wyborcza” z dnia 10 sierpnia, https://wyborcza.p1/7,155287,22211903,wyzszewymogi-przy-imporcie-gazu-czy-ceny-surowca-wzrosna.html.

EUGAL. https://www.eugal.de/eugal-pipeline/trassenverlauf/.

Jakóbik Wojciech. 2016. Waszczykowski za szybko grzebie Nord Stream 2, http://biznesalert.pl/jakobik-waszczykowski-szybko-grzebie-nord-stream-2/.

Komisja Europejska: Cf the European Commission's decision of 2009. https://ec.europa.eu/energy/sites/ener/files/documents/2009_opal_decision_de.pdf

Malinowski Dariusz. 2016. Gazociąg Opal - rosyjska macka w Europie, http://gazownictwo.wnp.pl/gazociag-opal-rosyjska-macka-weuropie,284347_1_0_0.html

Naftohaz. http://www.naftogaz.com/www/3/nakweben.nsf/0/FF8BE665665F161CC22580D 600655C50?OpenDocument $\&$ year $=2017 \&$ month $=03 \& n t=$ News $\&$,

Pirani Simon, Yafimava Katja. 2016. Russian Gas Transit across Ukraine Post-2019: Pipeline Scenarios, Gas Flow Consequences, and Regulatory Constraints, Oxford: Oxford Institute for Energy Studies, February. OIES Paper, NG 105. https://www.oxfordenergy.org/wpcms/wp-content/uploads/2016/02/Russian-Gas-

Transit-Across-Ukraine-Post-2019-NG-105.pdf.

Polskie Górnictwo Naftowe i Gazownictwo. 2016. http://www.pgnig.pl/aktualnosci/-/newslist/id/pgnig-14-zarzutow-wobec-komisji-europejskiej-w-sprawieopal/newsGroupId/10184? changeYear=2016\&currentPage $=1$.

Polskie LNG. https://www.polskielng.pl/terminal-lng/terminal-lng-w-swinoujsciu/.

Puls Biznesu. 2019. Bundestag przyjął unijną dyrektywę gazową, https://www.pb.pl/bundestag-przyjal-unijna-dyrektywe-gazowa-975282.

Radio Maryja. 2016. Polski rząd zaskarżył do Trybunału UE decyzję KE ws. OPAL, http://www.radiomaryja.pl/informacje/polska-informacje/polski-rzad-zaskarzyltrybunalu-ue-decyzje-ke-ws-opalu/.

Radio Zachód. 2020. Gaz coraz tańszy: ceny prawie o 1/5 niższe niż pięć lat temu, publikacja z dnia 23 czerwca. https://www.zachod.pl/203264/gaz-coraz-tanszy-ceny-prawie-o-1-5nizsze-niz-piec-lat-temu/.

Urząd Regulacji Energetyki. https://www.ure.gov.pl/pl/urzad/wspolpraca-miedzynarod/ 2579, Trzeci-pakiet-energetyczny-w-Parlamencie-Europejskim.html.

Zaniewicz Maciej. 2019. O co chodzi z wyrokiem Trybunału Sprawiedliwości UE w sprawie OPAL? [Analiza], Energetyka 24, https://energetyka24.com/o-co-chodzi-z-wyrokiemtrybunalu-sprawiedliwosci-ue-ws-opal-analiza. 


\section{AKTY NORMATYWNE}

Traktat Lizboński (Dz. U. UE, C 306 z 17.12.2007).

Traktat o funkcjonowaniu Unii Europejskiej (TFUE), wersja skonsolidowana (Dz. U. UE C 326 $\mathrm{z}$ dn. 26.10.2012).

Układ o stowarzyszeniu między Unią Europejską i Europejską Wspólnotą Energii Atomowej oraz ich państwami członkowskimi z jednej strony, a Ukrainą z drugiej strony (Dz.U. L 161 z 29.5.2014).

Ustawa z dnia 10 kwietnia 1997 r. - Prawo energetyczne (tekst jednolity Dz.U.2019 poz.755).

Dyrektywa 98/30/EC Parlamentu Europejskiego i Rady Europy z dnia 22 czerwca 1998 r. dotycząca wspólnych zasad rynku wewnętrznego gazu ziemnego (Dz.U. L 176 z 15.7.2003).

Dyrektywa Parlamentu Europejskiego i Rady Europy 2009/73/WE z dnia 13 lipca 2009 r. dotycząca wspólnych zasad rynku wewnętrznego gazu ziemnego oraz uchylająca dyrektywę 2003/55/WE (Dz.U.C 211/94 z 14.08.2009).

\section{ORZECZNICTWO}

Sąd Unii Europejskiej, Komunikat prasowy nr 83/17 Luksemburg, 21 lipca 2017 r.https://curia.europa.eu/jcms/upload/docs/application/pdf/2017-07/cp170083pl.pdf.

Wyrok Sądu (dawniej: Sądu Pierwszej Instancji) z dnia 10 września 2019 r., sygn.T-883/16 https://sip.lex.pl/orzeczenia-i-pisma-urzedowe/orzeczenia-sadow/t-883-16rzeczpospolita-polska-przeciwko-komisji-522810995. 